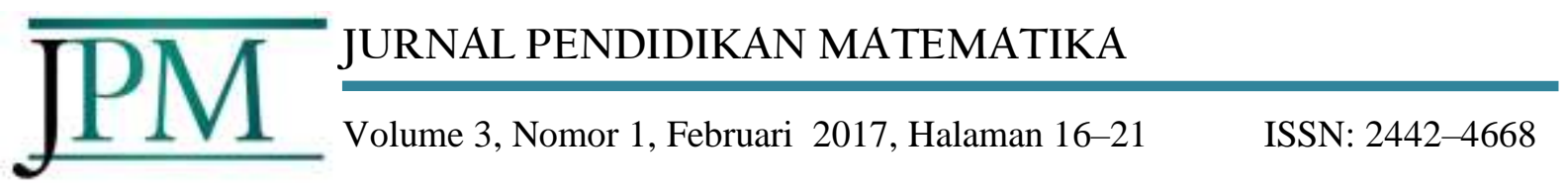

\title{
PENGEMBANGAN E-MODULE BERBASIS MULTIMEDIA INTERAKTIF DENGAN PENDEKATAN CONTEXTUAL TEACHING AND LEARNING (CTL) PADA POKOK BAHASAN STATISTIKA UNTUK SISWA KELAS X SMA/MA
}

\author{
Ardhanty Chaerunisa \\ Mahasiswa Program Studi Pendidikan Matematika FKIP Unisma \\ e-mail ardhanty.chaerunisa@yahoo.com
}

\begin{abstract}
Abstrak
Penelitian ini bertujuan untuk menghasilkan e-module berbasis multimedia interaktif dengan strategi pembelajaran Contextual Teaching and Learning (CTL) pada pokok bahasan statistika untuk kelas X SMA. Pengembangan e-module ini menggunakan model pengembangan Four-D. Model tersebut terdiri dari 4 tahap yaitu, Define, Design, Develop, dan Disseminate. E-module ini divalidasi oleh tiga validator yang meliputi satu ahli pengembang bahan ajar, satu ahli materi, dan satu praktisi guru matematika SMA. Setelah $e$-module dinyatakan valid, kemudian diujicobakan kepada siswa. Subjek uji coba pengembangan e-module ini merupakan subjek uji coba dalam kelompok kecil yang terdiri dari 12 siswa kelas X di MAN 1 Malang. Uji coba dilakukan untuk mengetahui kelayakan e-module untuk digunakan dalam proses pembelajaran. Berdasarkan hasil analisis data validasi ahli dan praktisi, secara keseluruhan $e$-module yang dikembangkan dinyatakan valid dengan hasil rata-rata penilaian sebesar 3,45 dan telah memenuhi kriteria kevalidan yang ditetapkan. Sedangkan pada uji coba user, e-module dinyatakan valid dengan diperoleh rata-rata hasil penilaian sebesar 3,72. Berdasarkan hasil analisis tersebut, dapat disimpulkan bahwa $e$ module telah memenuhi kriteria layak digunakan dalam proses pembelajaran.
\end{abstract}

Kata kunci: pengembangan, e-module, strategi, $c t l$, statistika

\section{PENDAHULUAN}

Pendidikan merupakan proses yang berkesinambungan, dimulai dari pendidikan usia dini sampai dengan perguruan tinggi. Oleh karena itu, proses pendidikan yang berkesinambungan ini perlu mendapat perhatian dan prioritas utama agar potensi sumber daya manusia melalui kegiatan pembelajaran bisa terus berkembang. Dalam dunia pendidikan, matematika merupakan suatu disiplin ilmu yang bersifat universal, artinya matematika mempunyai peran penting untuk memajukan daya nalar manusia. Dari hasil analisis angket kebutuhan siswa yang dilakukan di MAN 1 Malang diperoleh hasil persentase $84,62 \%$ sangat setuju tentang penggunaan bahan ajar yang bervariasi sangat mempengaruhi dalam pemahaman matematika siswa.

Banyak bahan ajar yang telah beredar dan digunakan di sekolah. Namun sebagian besar konsep materi yang terdapat dalam bahan ajar yang digunakan di sekolah selama ini kurang mengarahkan siswa untuk dapat menemukan konsep dan rumus secara mandiri. Pemilihan bahan ajar yang efektif sangat dibutuhkan agar siswa dapat memahami dan menemukan konsep pembelajaran. Menurut Belawati, dkk (dalam Prastowo, 2013:40) terdapat bermacam-macam bahan ajar, salah satunya adalah bahan ajar pandang (visual) seperti modul. Modul terdiri dari materi pelajaran yang disusun untuk membantu siswa mencapai sejumlah tujuan yang dirumuskan secara khusus dan jelas. Modul dapat memfasilitasi siswa dalam mempelajari berbagai materi, salah satunya adalah materi pelajaran matematika.

Berkembangnya ilmu dan teknologi membawa paradigma baru terhadap bahan ajar cetak seperti modul. Produk TI (Teknologi Informasi) dewasa ini telah memberikan alternatif berupa 
modul yang dapat digunakan dan diakses siswa yang tidak dalam bentuk cetak, tetapi berbentuk softfile dengan komputer sebagai perangkat utama. Dalam sistem yang lebih kompleks, bahan ajar modul yang berbentuk softfile dikenal dengan $e$-module.

E-module merupakan salah satu bahan ajar yang proses penerbitannya dalam bentuk digital terdiri dari teks, gambar atau gabungan keduanya yang bisa dibaca lewat komputer atau alat elektronik. Awalan "e" dalam e-module berarti elektronik yang secara implisit dimaknai teknologi elektronika digital, sementara modul adalah salah satu bahan ajar yang disajikan secara sistematis, sehingga penggunanya dapat belajar dengan atau tanpa seorang fasilitator atau guru (Prastowo, 2013:104).

Salah satu kriteria e-module adalah self intructional yang artinya e-module mampu membelajarkan siswa secara mandiri (Asyhar, 2012:155). Salah satu landasan teori pendidikan modern yang dapat membelajarkan siswa secara mandiri adalah pembelajaran dengan pendekatan Contextual Teaching and Learning (CTL). CTL merupakan teori pembelajaran konstruktivistik. Terdapat lima karakteristik penting dalam proses pembelajaran yang menggunakan pendekatan CTL, yaitu: activiting knowledge (pembelajaran merupakan proses pengaktifan pengetahuan yang sudah ada), acquiring knowledge (belajar dalam rangka memperoleh dan menambah pengetahuan baru), understanding knowledge (pemahaman pengetahuan), applying knowledge (mempraktikan pengetahuan dan pengalaman tersebut), dan reflecting knowledge (melakukan refleksi).

Dari uraian di atas, secara umum penelitian ini bertujuan untuk menghasilkan bahan ajar berupa e-module berbasis multimedia interaktif dengan pendekatan Contextual Teaching and Learning (CTL) pada pokok bahasan statistika untuk siswa kelas X SMA/MA. Secara teoritis hasil pengembangan ini diharapkan dapat memberikan sumbangan pada perkembangan keilmuan, terutama pada pengembangan bahan ajar. Selain itu, secara praktis hasil pengembangan diharapkan dapat meberikan manfaat bagi guru dan siswa sebagai alternatif pemilihan bahan ajar dalam penyampaian materi statistika.

CTL disebut pendekatan kontekstual karena proses belajar yang membantu guru mengaitkan antara materi yang diajarkan dengan situasi dunia nyata siswa yang mendorong siswa membuat hubungan antara pengetahuan yang dimilikinya dengan penerapannya dalam kehidupan mereka sebagai anggota masyarakat. "Contextual Teaching and Learning (CTL) membuat siswa mampu menghubungkan isi dari subjek-subjek akademik dengan konteks kehidupan keseharian mereka untuk menemukan makna" (Johnson, 2014:64). Pembelajaran kontekstual terjadi apabila siswa menerapkan dan mengalami apa yang sedang diajarkan dengan mengacu pada masalahmasalah dunia nyata.

Dalam Sa'ud (2010:168) pendekatan CTL memiliki tujuh komponen utama yaitu: konstruktivisme (construktivism), inkuiri (inquiry), bertanya (questioning), masyarakat belajar (learning community), pemodelan (modeling), refleksi (reflection) dan penilaian sebenarnya (authentic assessment).

Dari ketujuh komponen utama pembelajaran kontekstual di atas, maka peneliti memanfaatkan sebagian dari komponen tersebut sebagai pendekatan dalam pengembangan sesuai dengan media yang dikembangkan, yaitu konstruktivisme, menemukan, bertanya, pemodelan dan refleksi. Adapun alasan tidak memilih kedua komponen tersebut adalah karena strategi learning community (masyarakat belajar) tidak sesuai dengan ciri-ciri e-module dan Authentic Assessment (Penilaian Nyata) tidak perlu dilakukan oleh pengembang pada saat penelitian.

E-module berbasis multimedia interaktif dengan pendekatan CTL adalah modul elektronik dalam bentuk digital yang didesain secara interaktif dengan isi materi mengandung kegiatan dari pendekatan CTL, yaitu konstruktivisme (construktivism), inkuiri (inquiry), bertanya (questioning), masyarakat belajar (learning community), pemodelan (modeling), refleksi (reflection) dan penilaian sebenarnya (authentic assessment) dengan alat penunjang komputer atau alat elektronik lainnya.

Karakteristik e-module berbasis multimedia interaktif yang akan dikembangkan dalam penulisan skripsi ini adalah sebagai berikut. 
1. Kompetensi Inti (KI) dan kompetensi Dasar (KD) yang digunakan dalam $e$-module mengacu pada kompetensi inti yang terdapat pada Standar isi (SI).

2. Kurikulum yang digunakan sebagai acuan dalam pengembangan e-module berbasis multimedia interaktif dengan pendekatan Contextual Teaching and Learning (CTL) ini adalah kurikulum 2013.

3. E-module berbasis multimedia interaktif dengan pendekatan Contextual Teaching and Learning (CTL) menggunakan software Adobe Flash CS5.

4. Materi yang disajikan dalam e-module berbasis multimedia interaktif dengan pendekatan Contextual Teaching and Learning (CTL) diangkat dari permasalahan kehidupan sehari-hari.

5. Kegiatan yang disajikan bertujuan untuk membantu siswa mencapai tujuan pembelajaran yang akan dicapai dan memudahkan siswa dalam memahami materi.

6. E-module memuat materi, permasalahan, kesimpulan, dan evaluasi dengan kehidupan seharihari sehingga siswa dapat mengkonstruk sendiri pemahaman mereka terhadap materi yang dipelajari.

7. Font penulisannya tidak menggunakan font resmi saja, background full color, dilengkapi dengan animasi dan gambar-gambar yang menarik.

\section{METODE PENGEMBANGAN}

Model pengembangan yang digunakan dalam penelitian ini adalah model prosedural. Model pengembangan prosedural yaitu model deskriptif yang menggambarkan alur atau langkah-langkah prosedural yang harus diikuti untuk menghasilkan suatu produk tertentu. Model prosedural biasanya berupa urutan langkah-langkah yang diikuti secara bertahap dari langkah awal hingga akhir (Setyosari, 2013:230).

Sebagaimana telah dijelaskan sebelumnya, tujuan pengembangan ini adalah menghasilkan $e$ module berbasis multimedia interaktif dengan pendekatan Contextual Teaching and Learning (CTL) pada pokok bahasan statistika untuk siswa kelas X SMA. Oleh karena itu, untuk menghasilkan $e$-module yang efisien maka diperlukan adanya perencanaan yang baik dalam proses pengembangan, agar tujuan pengembangan dapat tercapai secara maksimal. Dalam pengembangan ini model prosedural yang digunakan adalah model pengembangan Four-D yang direkomendasikan oleh Thiagarajan, Semmel dan Semmel (dalam Trianto, 2011:189-192).

Model ini terdiri atas empat tahap yaitu: (1) Define (Pendefinisian), (2) Design (Perancangan), (3) Develop (Pengembangan), dan (4) Disseminate (Penyebaran). Alasan pemilihan model pengembangan 4-D adalah karena model 4-D sesuai untuk mengembangkan bahan ajar berupa $e$-module.

\section{Prosedur Pengembangan}

Adapun prosedur pengembangan e-module berbasis multimedia interaktif dengan pendekatan Contextual Teaching and Learning (CTL) menggunakan model pengembangan 4-D.

Pertama, tahap define (pendefinisian). Tujuan dari tahap ini adalah untuk menetapkan dan mendefinisikan syarat-syarat penyusunan $e$-module berbasis multimedia interaktif dengan pendekatan Contextual Teaching and Learning (CTL) dengan cara melakukan analisis yang meliputi analisis ujung depan, analisis siswa, analisis tugas, analisis konsep serta merumuskan tujuan pembelajaran.

Kedua, tahap design (perancangan). Tujuan dari tahap ini adalah untuk merancang $e$-module berbasis multimedia interaktif dengan pendekatan Contextual Teaching and Learning (CTL). Pada tahap perancangan terdapat tiga langkah yang harus dilakukan, yaitu: membuat desain $e$-module dalam bentuk flowchart dan storyboard, memprogram e-module dengan menggunakan software Adobe Flash CS5, dan menyusun angket penilaian e-module. Pada tahap ini diperoleh draf I $e$ module. 
Ketiga, tahap develop (pengembangan). Pada tahap ini dilakukan penilaian terhadap draf I $e$ module kepada tiga validator, yaitu validator ahli pengembang bahan ajar, validator ahli materi dan validator praktisi. Setelah tiga validator memvalidasi draf I e-module, kemudian peneliti menganalisis hasil angket penilaian $e$-module yang telah diberikan kepada validator. Apabila draf I $e$-module valid, maka dihasilkan draf II e-module. Tetapi jika draf I $e$-book belum valid, maka peneliti harus melakukan revisi terlebih dahulu kemudian dikembalikan ke validator. Jika sudah valid, draf II e-module diujicobakan pada kelompok kecil yang melibatkan 12 siswa kelas X MAN 1 Malang.

Keempat, tahap disseminate (penyebaran). Tahap ini merupakan tahap penggunaan $e$-module yang telah dikembangkan pada skala yang lebih luas. Pada tahap ini produk yang dihasilkan sudah berupa produk akhir yaitu e-module berbasis multimedia interaktif dengan pendekatan Contextual Teaching and Learning (CTL) pada pokok bahasan statistika untuk siswa kelas X SMA. Peneliti melakukan penyebaran e-module melalui blog yang bisa diakses pada alamat (http:umath19.blogspot.com).

\section{HASIL DAN PEMBAHASAN}

Hasil dari pengembangan ini berupa e-module berbasis multimedia interaktif dengan pendekatan Contextual Teaching and Learning (CTL) pada pokok bahasan statistika untuk siswa kelas X SMA. Berdasarkan analisis ujung depan menunjukkan bahwa guru dan siswa membutuhkan dan ingin menggunakan bahan ajar e-module berbasis multimedia interaktif dengan pendekatan Contextual Teaching and Learning (CTL) dalam pembelajaran matematika. Sementara dari analisis siswa diperoleh motivasi belajar siswa dalam memahami matematika sangat tinggi. Analisis tugas diperoleh materi yang dikembangkan dalam e-module adalah materi statistika yang disesuaikan berdasarkan standar isi kurikulum 2013 serta KI dan KD dalam materi statistika. Sedangkan pada analisis konsep disusun indikator yang sesuai dengan KI dan KD yang dipilih pada analisis tugas..

Cover ditampilkan dengan warna yang full colour, menarik dan gambar tema yang sesuai dengan materi statistika. Tampilan halaman sampul (cover) dapat dilihat pada Gambar 1 berikut.

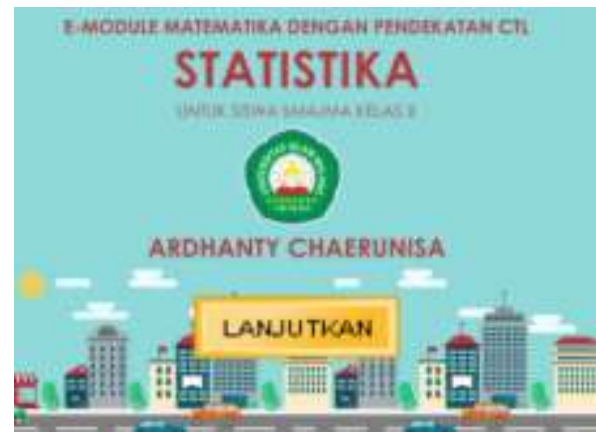

Gambar 1 Tampilan Halaman Sampul

Pada halaman inti terdiri dari beberapa halaman yang berisi seluruh materi tentang statistika. Halaman bahan ajar $e$-module didesain sangat menarik. Tampilan halaman inti dapat dilihat pada Gambar 2 berikut.

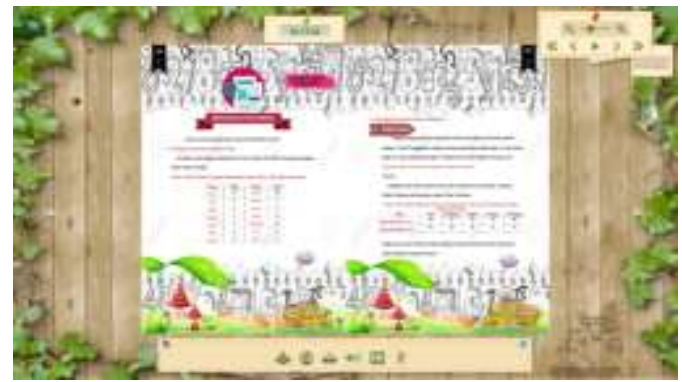

Gambar 2. Tampilan Halaman Inti 
Pada back cover terdapat uraian singkat mengenai sajian isi e-module. Tampilan halaman penutup dapat dilihat pada Gambar 3 berikut.

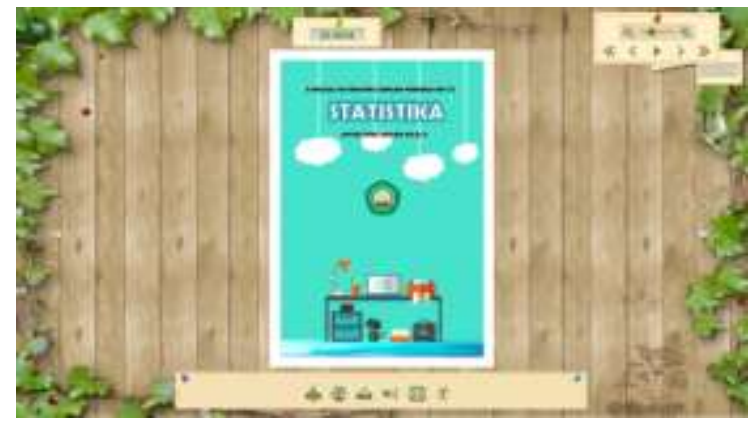

\section{Gambar 3 Tampilan Halaman Penutup}

E-module ini divalidasi oleh tiga validator yang meliputi satu ahli pengembang bahan ajar, satu ahli materi, dan satu praktisi guru matematika MAN 1 Malang. Berdasarkan hasil analisis data validasi ahli dan praktisi, diperoleh data sebagai berikut: (1) rata-rata total validator ahli pengembang bahan ajar adalah 3,18, (2) rata-rata total validator ahli materi adalah 3,44, dan (3) rata-rata total validator praktisi adalah 3,74. Kemudian hasil validasi dari ketiga validator tersebut dikelompokkan menjadi satu data utuh untuk menyatakan kevalidan $e$-module berbasis multimedia interaktif dengan pendekatan CTL pada pokok bahasan statistika dan diperoleh nilai rata-rata total dari semua validator adalah 3,45. Maka berdasarkan kriteria kevalidan yang telah ditentukan, $e$ module dengan pendekatan CTL dinyatakan valid. Setelah e-module dinyatakan valid, kemudian diujicobakan kepada 12 siswa kelas X MAN 1 Malang. Rata-rata total penilaian dari kelompok pengguna adalah 3,72, maka dapat ditarik kesimpulan bahwa untuk e-module berbasis multimedia interaktif dengan pendekatan Contextual Teaching and Learning (CTL) pada pokok bahasan statistika dinyatakan valid.

Pengembangan e-module berbasis multimedia interaktif dengan pendekatan CTL ini memiliki perbedaan dalam hal tampilan dan penyajian materi. Kelebihan dari $e$-module berbasis multimedia interaktif dengan pendekatan Contextual Teaching and Learning (CTL) adalah sebagai berikut:

1. E-module memberikan umpan balik (feedback) sehingga siswa dapat mengetahui taraf hasil belajarnya.

2. E-module interaktif dengan strategi pembelajaran CTL dapat membimbing siswa menemukan konsep materi secara mandiri.

3. E-module memberikan tantangan kepada siswa untuk benar-benar memahami konsep agar bisa mengaplikasikan ke dalam latihan soal atau evaluasi.

\section{PENUTUP}

Berdasarkan hasil pengembangan yang menggunakan model pengembangan Four-D menghasilkan e-module berbasis multimedia interaktif dengan pendekatan Contextual Teaching and Learning (CTL) pada pokok bahasan statistika. Cakupan materi yang dikembangkan dalam bahan ajar e-module interaktif dengan pendekatan CTL ini masih belum terlalu luas, hanya membahas tentang statistika saja, maka disarankan untuk memperluas materi atau menambah materi yang lain. Selain itu, dalam tahap uji coba, pengembang hanya menggunakan uji coba dalam kelompok kecil dan penyebaran melalui blog. Sehingga, disarankan untuk selanjutnya dilakukan uji coba dalam kelompok besar dan menguji e-module hingga keefektifannya.

\section{DAFTAR RUJUKAN}

Asyhar, Rayandra. 2012. Kreatif Mengembangkan Media Pembelajaran. Jakarta: Referensi. Darmawan, Deni. 2012. Inovasi Pendidikan. Bandung: Remaja Rosdakarya. 
Hamdani. 2011. Strategi Belajar Mengajar. Bandung: Pustaka Setia.

Jhonson, Elaine. CTL (Contextual Teaching and Learning. 2014. Bandung: Mizan Media Utama.

Munir. 2015. Multimedia Konsep dan Aplikasi dalam Pendidikan. Bandung: Alfabeta.

Prastowo, Andi. 2013. Panduan Kreatif Membuat Bahan Ajar Inovatif. Yogyakarta: Diva Press.

Sanjaya, Wina. 2006. Strategi Pembelajaran Berorientasi Standar Proses Pendidikan. Jakarta: Kencana Prenadamedia Grup.

Sa'ud, Udin Saefuddin. 2010. Inovasi Pendidikan. Bandung: Alfabeta.

Setyosari, Punaji. 2013. Metode Penelitian Pendidikan dan Pengembangan. Jakarta : Kencana Prenadamedia Group.

Sugiyono. 2014. Metode Penelitian Kuantitatif Kualitatif dan R\&D. Bandung: Alfabeta.

Sukmadinata, Nana Syaodih. 2013. Metode Penelitian Pendidikan. Bandung: PT Remaja Rosdakarya.

Sudjana, Nana. 2011. Penilaian Hasil Proses Belajar Mengajar. Bandung: PT Remaja Rosdakarya.

Trianto. 2011. Mendesain Model Pembelajaran Inovatif-Progresif. Jakarta: Kencana Prenada Media Group. 